\title{
Selenium Derivatives as Promising Therapy for Chagas Disease: In Vitro and In Vivo Studies
}

\author{
Rubén Martín-Escolano, Mikel Etxebeste-Mitxeltorena, Javier Martín-Escolano, Daniel Plano, \\ María J. Rosales, Socorro Espuelas, Esther Moreno, Manuel Sánchez-Moreno, Carmen Sanmartín, \\ and Clotilde Marín*
}

Cite This: ACS Infect. Dis. 2021, 7, 1727-1738

Read Online

ACCESS | Lلll Metrics \& More | 回 Article Recommendations | st Supporting Information

ABSTRACT: Chagas disease is a tropical infection caused by the protozoan parasite Trypanosoma cruzi and a global public health concern. It is a paradigmatic example of a chronic disease without an effective treatment. Current treatments targeting T. cruzi are limited to two obsolete nitroheterocyclic drugs, benznidazole and nifurtimox, which lead to serious drawbacks. Hence, new, more effective, safer, and affordable drugs are urgently needed. Selenium and their derivatives have emerged as an interesting strategy for the treatment of different prozotoan diseases, such as African trypanosomiasis, leishmaniasis, and malaria. In the case of Chagas disease, diverse selenium scaffolds have been reported with antichagasic activity in vitro and in vivo. On the basis of these premises, we describe the in vitro and in vivo trypanocidal activity

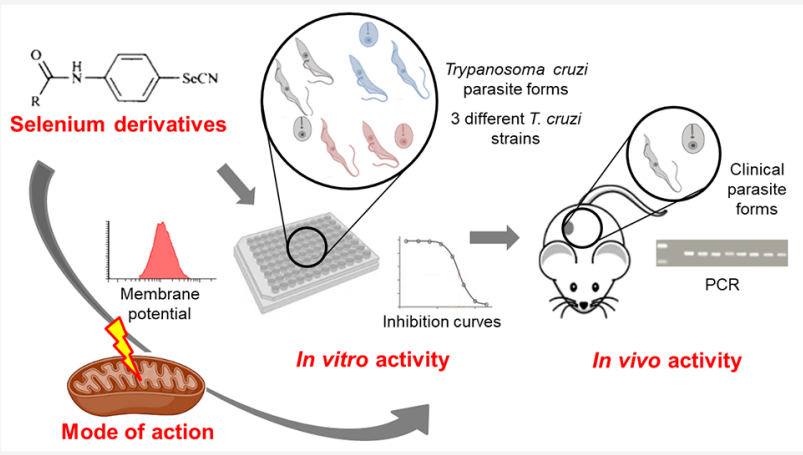
of 41 selenocompounds against the three morphological forms of different T. cruzi strains. For the most active selenocompounds, their effect on the metabolic and mitochondrial levels and superoxide dismutase enzyme inhibition capacity were measured in order to determine the possible mechanism of action. Derivative 26, with a selenocyanate motif, fulfills the most stringent in vitro requirements for potential antichagasic agents and exhibits a better profile than benznidazole in vivo. This finding provides a step forward for the development of a new antichagasic agent.

KEYWORDS: Chagas disease, chemotherapy, drug discovery, selenium derivatives, Trypanosoma cruzi

$\mathrm{C}$ hagas disease (CD) or American trypanosomiasis is a lifethreatening tropical infection caused by the insecttransmitted protozoan parasite Trypanosoma cruzi. CD is an important public health problem in Latin America, being the major cause of morbimortality in many endemic regions: It affects 6-7 million people, causing about 14 thousand deaths annually, and it is hypothesized that about 100 million people are living at risk of infection worldwide. ${ }^{1,2}$ Blood-sucking triatomine bugs (vectors) are the main transmission route, although the oral route involving parasite-contaminated food and drink, the congenital route, as well as blood transfusion, transplantation, and laboratory accidents are also important. ${ }^{3}$ $\mathrm{CD}$ has recently spread to nonendemic areas as a result of migratory flows, particularly in the United States and Europe. ${ }^{4,5}$

In mammalian hosts, $T$. cruzi is an obligate intracellular parasite which can infect most nucleated cells. ${ }^{6}$ The parasites become widely disseminated in tissues and organs and can be detected in the bloodstream during the initial acute phase of CD. Following suppression by the adaptive immune response, ${ }^{7}$ $\mathrm{CD}$ progresses to a long-lasting asymptomatic chronic stage with an extremely low parasite burden. However, about $30 \%$ of patients will progress to a symptomatic chronic CD, developing cardiomyopathy and digestive tract megasyndromes, among others, for which there are few therapeutic options. $^{8}$

Because of the gaps in knowledge about T. cruzi, the longterm nature of $\mathrm{CD}$, and its complex pathology, no vaccines are available. Currently, the front-line chemotherapy used to treat $\mathrm{CD}$ is limited to two obsolete drugs for more than 50 years: benznidazole (BZN) and nifurtimox (NFX). These drugs lead to serious drawbacks, such as a range of toxic side-effects, extended treatment length and frequent treatment failures. ${ }^{9,10}$ Furthermore, the well-known cross-resistance-both drugs require metabolic activation within the parasite by the same mitochondrial nitroreductase $e^{11}-$ and the natural variation in

Received: January 26, 2021

Published: April 19, 2021 


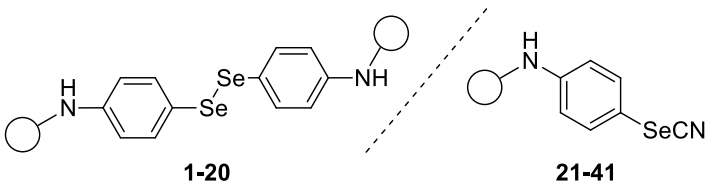<smiles>CCC(C)C(=O)c1ccccc1</smiles>

1, 21<smiles>CCC(=O)c1ccc(Cl)cc1</smiles>

2,22<smiles>COc1ccc(C(=O)C(C)C)cc1</smiles>

3,23<smiles>CCC(C)C(=O)c1ccc(C#N)cc1</smiles>

4, 24<smiles>CC(C)C(=O)c1ccc([N+](=O)[O-])cc1</smiles>

5,25<smiles>CCC(=O)c1ccc(C(F)(F)F)cc1</smiles>

6, 26<smiles>CCC(C)C(=O)c1ccc(C)cc1</smiles><smiles>CCC(C)C(=O)c1cccs1</smiles><smiles>CCC(C)C(=O)c1ccno1</smiles><smiles>O=C1CC2CC3CC(C2)CC1C3</smiles><smiles>CC(C)(C)C(=O)/C=C/c1ccccc1</smiles>

12,32<smiles>CCC(C)C(=O)c1cccc2ccccc12</smiles><smiles>CCCCC(=O)c1ccc(C(C)C)cc1</smiles>

11,31

13,33<smiles>[3H]P(=O)(Oc1ccccc1)Oc1ccccc1OP(=O)(OC)OP(=O)(OC)OC</smiles><smiles>CCOP(=O)(CC)OCC</smiles><smiles>CCOP(=O)(O)OCC</smiles>

18, 39
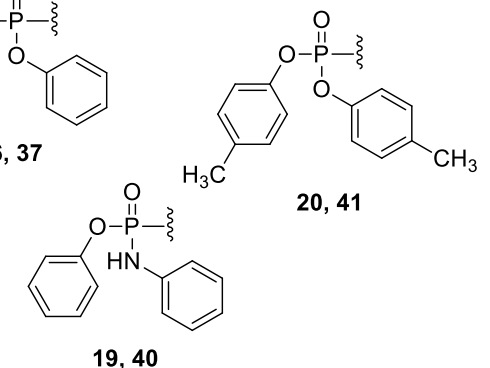

20, 41

Figure 1. Structures of the 41 selenocompounds.

susceptibility to drugs due to the extreme diversity of species ${ }^{12}$ make crucial the international effort aimed at developing new drugs against $\mathrm{CD}$.

In this context, selenium ( $\mathrm{Se}$ ) and their derivatives have emerged as an interesting strategy for the treatment of different trypanosomiasis. Previous studies of our research group have shown that different selenocompounds exhibited promising activity against visceral leishmaniasis. ${ }^{13-17}$ Moreover, selenocompounds have displayed activity against malaria, ${ }^{18}$ African trypanosomiasis, ${ }^{19}$ or intestinal schistosomiasis. ${ }^{20}$ In the case of $\mathrm{CD}$, several studies confirmed an association between the chronification of the disease and the decrease of Se plasma levels. ${ }^{21}$ In addition, Se supplementation therapies modulated the antioxidant, immune, and inflammatory responses, thus improving the intestinal megasyndrome, ${ }^{22}$ the placental immune response in pregnancy cases, ${ }^{22}$ and especially Chagasic cardiomyopathy problems. ${ }^{23,24}$ During the last years, diverse selenium scaffolds such as selenosemicarbazones, ${ }^{25}$ Se lapachones, ${ }^{26}$ Se quinones, ${ }^{27}$ Se naphtoquinones, ${ }^{28}$ and selenocyanates ${ }^{29}$ have been reported with antichagasic activity in vitro and in vivo. On the basis of these premises, and in connection with the interesting properties of selenium derivatives for the treatment of $\mathrm{CD}^{30}$ in the present contribution, we describe the in vitro and in vivo trypanocidal activity of 41 selenocompounds against the three morphological forms of three different $T$. cruzi strains. In order to expand the chemical space and the molecular diversity several selenoamides and selenophosphoramidates containing seleno- cyanate and diselenide motifs have been selected (Figure 1). For the most active and selective selenocompounds, its effect on the metabolite excretion, mitochondrial membrane potential, DNA or RNA alteration, and Fe-superoxide dismutase (SOD) enzyme inhibition capacity were measured in order to determine the possible mechanism of action.

\section{RESULTS AND DISCUSSION}

In Vitro Evaluation. Taking into account the parasite's genetic diversity, drug resistance, the different sensitivities against moieties, and the $\mathrm{CD}$ target product profile established by the Drugs for Neglected Diseases initiative (DNDi), ${ }^{10,31}$ compounds and BZN were evaluated against three different $T$. cruzi strains belonging to different discrete typing units (DTUs) associated with the human parasitosis. Moreover, the compounds' effects on the viability and growth of the host cells was evaluated against Vero cells.

First, in vitro evaluation screening was performed using the extracellular epimastigotes because of their simple culture. The results, summarized in Table $S 1$, are expressed as the inhibitory concentration $50\left(\mathrm{IC}_{50}\right)$. Otherwise, selectivity index (SI) was calculated as the ratio between $\mathrm{IC}_{50}$ values of compounds against Vero cells relative to those against $T$. cruzi epimastigotes.

Compounds with SI values higher than 10 in at least one T. cruzi strain advanced to the in vitro activity assessment against the developed forms in vertebrate hosts (amastigotes and trypomastigotes); these are the relevant forms from a clinical 
Table 1. Activity of Benznidazole and Selected Selenocompounds Tested against Cultured Amastigote and Trypomastigote forms of Trypanosoma cruzi Strains

\begin{tabular}{|c|c|c|c|c|c|c|}
\hline \multirow[b]{3}{*}{ comp. } & \multicolumn{6}{|c|}{ activity $\mathrm{IC}_{50}(\mu \mathrm{M})^{a}$} \\
\hline & \multicolumn{2}{|c|}{ Arequipa strain } & \multicolumn{2}{|c|}{ SN3 strain } & \multicolumn{2}{|c|}{ Tulahuen strain } \\
\hline & am. forms & trypom. forms & am. forms & trypom. forms & am. forms & trypom. forms \\
\hline $\mathrm{BZN}$ & $8.3 \pm 0.7$ & $12.4 \pm 1.1$ & $16.6 \pm 1.4$ & $36.1 \pm 3.1$ & $10.0 \pm 0.8$ & $15.1 \pm 1.3$ \\
\hline 25 & $49.3 \pm 4.1$ & $35.8 \pm 5.8$ & nd & nd & $>50.0$ & $42.2 \pm 3.9$ \\
\hline 26 & $5.4 \pm 0.7$ & $2.4 \pm 0.3$ & $3.9 \pm 0.5$ & $2.5 \pm 0.3$ & $4.9 \pm 0.3$ & $2.9 \pm 0.2$ \\
\hline 28 & $3.2 \pm 0.4$ & $1.8 \pm 0.1$ & $1.7 \pm 0.4$ & $1.7 \pm 0.2$ & $2.7 \pm 0.3$ & $1.8 \pm 0.2$ \\
\hline 29 & $15.4 \pm 2.0$ & $12.7 \pm 1.2$ & nd & nd & nd & nd \\
\hline 33 & nd & nd & $16.9 \pm 1.4$ & $14.1 \pm 1.1$ & nd & nd \\
\hline
\end{tabular}

${ }^{a}$ Inhibition concentration $50\left(\mathrm{IC}_{50}\right)$ : concentration $(\mu \mathrm{M})$ required to inhibit $50 \%$ population, determined using GraphPad Prism 6 . BZN, benznidazole. nd, not determined.

Table 2. Selectivity Index for Benznidazole and Selenocompounds on Amastigotes and Trypomastigotes of Trypanosoma cruzi Strains

\begin{tabular}{|c|c|c|c|c|c|c|}
\hline \multirow[b]{3}{*}{ comp. } & \multicolumn{6}{|c|}{ selectivity index $(\mathrm{SI})^{a}$} \\
\hline & \multicolumn{2}{|c|}{ Arequipa strain } & \multicolumn{2}{|c|}{ SN3 strain } & \multicolumn{2}{|c|}{ Tulahuen strain } \\
\hline & am. forms & trypom. forms & am. forms & trypom. forms & am. forms & trypom. forms \\
\hline $\mathrm{BZN}$ & 10 & 7 & 5 & 2 & 8 & 5 \\
\hline 25 & $10(1)$ & $14(2)$ & nd & nd & nd & nd \\
\hline 26 & $25(3)$ & $56(8)$ & $34(7)$ & $52(26)$ & $27(3)$ & $46(9)$ \\
\hline 28 & $28(3)$ & $50(7)$ & $53(11)$ & $53(26)$ & $33(4)$ & $50(10)$ \\
\hline 29 & $4(0)$ & $5(1)$ & nd & nd & nd & nd \\
\hline 33 & nd & nd & $3(1)$ & $4(2)$ & nd & nd \\
\hline
\end{tabular}

${ }^{a}$ Selectivity index (SI): $\mathrm{IC}_{50}$ Vero cells/ $\mathrm{IC}_{50}$ developmental forms of the parasite. Data in parentheses refer to the number of times that compounds exceed the reference drug SI. BZN, benznidazole. nd, not determined.

point of view and the forms responsible for the acute and chronic CD. ${ }^{32}$ Therefore, compounds $25,26,28,29$, and 33 were selected to evaluate their $\mathrm{IC}_{50}$ and $\mathrm{SI}$ values against the amastigotes and trypomastigotes over the three strains (Tables 1 and 2). Interestingly, diselenide derivatives did not show activity at all against $T$. cruzi epimastigotes as it happens against Leishmania infantum. ${ }^{33}$ In contrast, 14 out of the 20 selenocyanate derivatives presented $\mathrm{IC}_{50}$ values lower than 20 $\mu \mathrm{M}$ at least in one of the strains, and 12 of them presented $\mathrm{IC}_{50}$ values lower than $10 \mu \mathrm{M}$ in at least in one of the strains.

The criteria established for this in vitro screening as the cutoff of this step were the same as those according to the literature: ${ }^{34,35} \mathrm{IC}_{50}<10 \mu \mathrm{M}$ and $\mathrm{SI}>50$ (in at least two strains and one parasitic form). Therefore, compounds 26 and 28 were prioritized as potential compounds, and they were chosen for the subsequent in vivo evaluation. Moreover, these compounds were active against the three T. cruzi strains (including the BZN-resistant SN3 strain), devoid of drug resistance.

Before going ahead with in vivo studies, the infection rates in Vero cells were evaluated by counting the infected cells after $72 \mathrm{~h}$ of treatment with compounds 26 and 28 . Results are summarized in Figure 2, together with the previously determined $\mathrm{IC}_{50}$ values against amastigotes and trypomastigotes of the Arequipa strains. It was found that the rates of infection (and the total number of amastigotes and trypomastigotes) decreased as the concentrations of compounds and BZN increased.

The average number of amastigotes per cell was also measured (Figure S1), giving an idea of the killing rate. This value was measured after $72 \mathrm{~h}$ of exposure at different concentrations of compounds and BZN, and the data show that compounds exhibit behavior similar to $\mathrm{BZN}$, which is considered as a fast-acting compound. ${ }^{36}$ The number of amastigotes per cell gradually decreased in all cases after $72 \mathrm{~h}$ of exposure, highlighting that the effect of tested compounds at $50 \mu \mathrm{M}$ reduced the number of amastigotes to practically zero. These data show that the compounds not only inhibit parasite multiplication but also cause its death. All these features are additional advantages since fast-acting and trypanocidal compounds can eliminate the parasite in a few doses, ${ }^{37}$ as well as act against the newfound quiescent or dormant amastigote form (responsible form of relapses after chemotherapy). ${ }^{38}$

In Vivo Anti-T. cruzi Activity in BALB/c Mice. Considering the results obtained from in vitro assays, compounds 26 and 28 were selected as promising drugs for in vivo evaluation in $\mathrm{BALB} / \mathrm{c}$ mice. These trials were performed using only the T. cruzi Arequipa strain in order to reduce the number of animals tests, as there were no significant differences for the other evaluated strains.

As currently used clinical drugs presented variable activity in the acute and the chronic phase of the disease, ${ }^{39}$ compounds were evaluated in both phases according to the experiments established in Scheme 1. It should be noted that most in vivo testing has focused on acute $\mathrm{CD}$, partially because it is simpler to monitor parasite burden. ${ }^{40}$ However, the ability to cure chronic $C D$ is the main need from a clinical point of view. ${ }^{31}$ Therefore the different phase-specific drugs responses highlight that chronic CD should be the main research focus in animal models.

$\mathrm{BALB} / \mathrm{c}$ mice were intraperitoneally infected according to a literature procedure. ${ }^{41}$ Compounds 26 and $\mathbf{2 8}$ or BZN were administered intraperitoneally from 9 days post-infection 

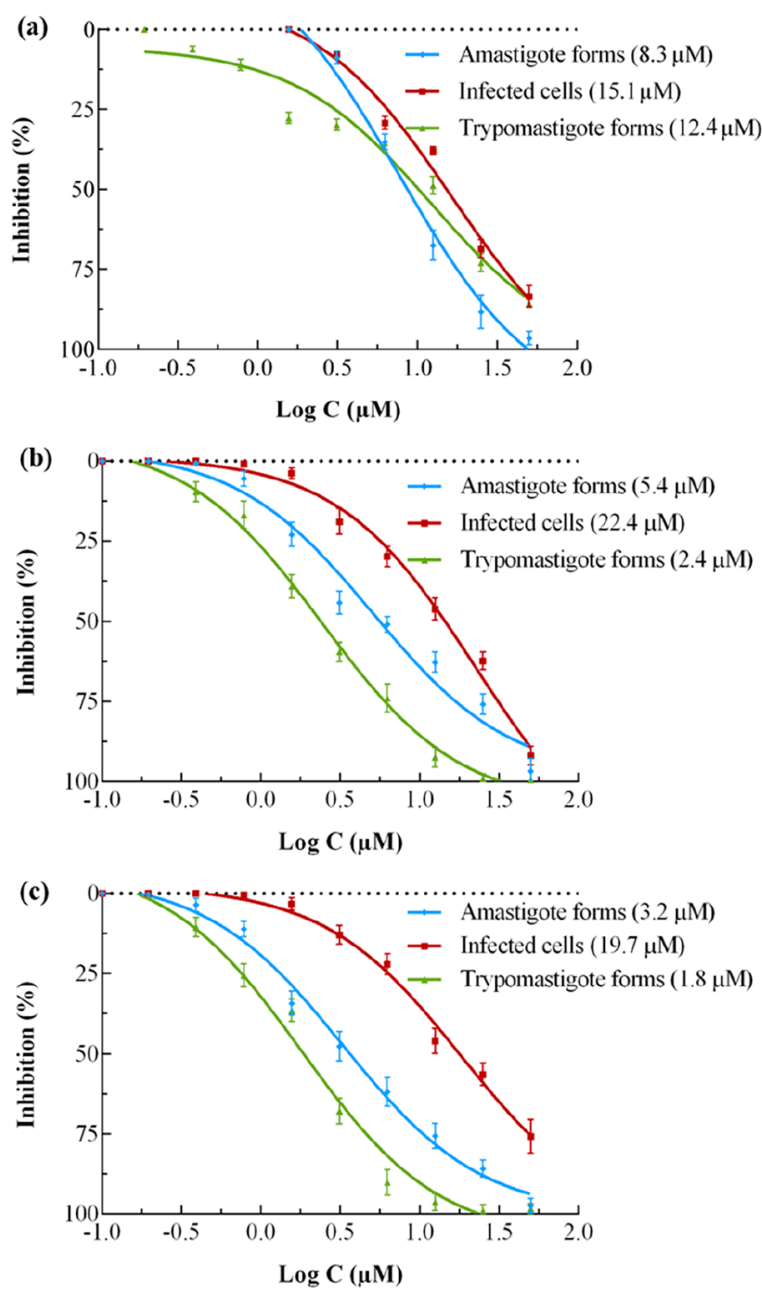

Figure 2. Infection of Trypanosoma cruzi Arequipa strain regarding the amastigotes and trypomastigotes and infected cells treated with (a) benznidazole, (b) 26, and (c) 28. Values constitute means of three independent experiments \pm standard deviation. Data in parentheses refer to the $\mathrm{IC}_{50}$ value, calculated using GraphPad Prism 6. (dpi), once daily for 5 consecutive days at a dose of $20 \mathrm{mg}$. $\mathrm{kg}^{1-}$. This dosage represents the subcurative dose of BZN, so the experiment demonstrated whether the studies compound are more effective or not than the reference drug during the disease progress. In addition, it is shown that a compound showing a reasonable reduction in parasitaemia following 5 consecutive days of treatment can be considered a lead compound. ${ }^{36}$

First, parasitaemia levels of the four studies groups during the acute phase were determined by counting bloodstream trypomastigotes (BTs) as described in the "Methods" section (Figure 3A). Compound $\mathbf{2 8}$ showed a slight antiparasitic activity over the first month becoming similar to the BZN activity after 40 days. Compound 26 demonstrated a better activity profile compared to that of BZN, with low parasitaemia levels over the completely acute phase for 48 days. It is important to note that compound 26 caused an evident reduction of parasitaemia from the beginning of the treatment, even disappearing on $12 \mathrm{dpi}$. In addition, the parasitaemia of mice treated with compound 26 was resolved at $48 \mathrm{dpi}$, that is, 7 days before the parasitaemia of the untreated mice and those treated with BZN.

Second, the experimental cure was evaluated using a double checking widely used in animal models to evaluate the treatment effectiveness: immunosuppression (IS) and PCR of the target organs/tissues. Animals whose parasitaemia reactivation does not reappear and show negative PCR data after IS are considered cured. ${ }^{42}$

At $115 \mathrm{dpi}$, mice were immunosuppressed with cyclophosphamide monohydrate (CP) in order to assess the effectiveness of the treatments in acute and chronic CD. This procedure expands the residual infection to detectable levels in there is still presence of parasite after treatment. ${ }^{43}$ Figure $3 \mathrm{~B}$ shows the reactivation percentages of infection for each group of mice compared to those of the untreated (control) group after the immunosuppression. As observed, mice treated with BZN and compound 26 showed a similar parasitaemia reactivation. Compound 26 showed a reactivation of approximately 65 and $60 \%$ in acute and chronic phases respectively, being slightly more effective than BZN. However, mice treated with compound $\mathbf{2 8}$ showed a high parasitaemia

Scheme 1. Timeline for All In Vivo Assays on BALB/c Mice for the Evaluation of Compounds in the Acute and Chronic Phases of Chagas Disease ${ }^{a}$

\section{Acute phase evaluation}

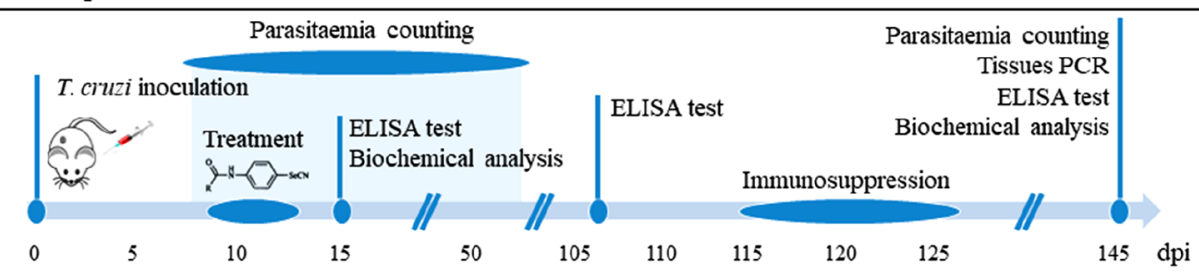

Chronic phase evaluation

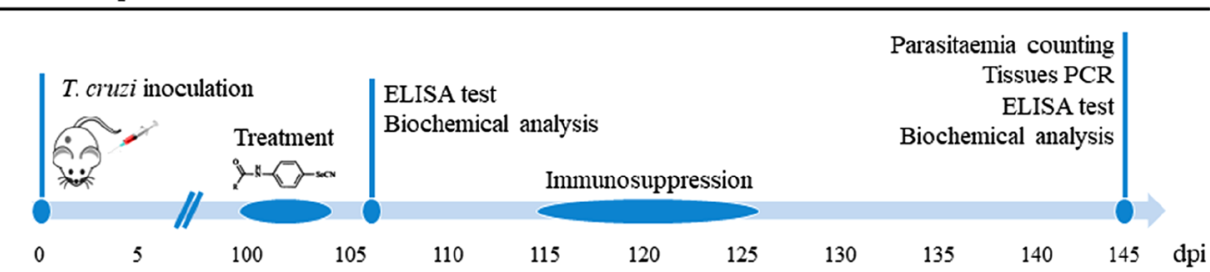

${ }^{a} \mathrm{dpi}=$ days post-infection 

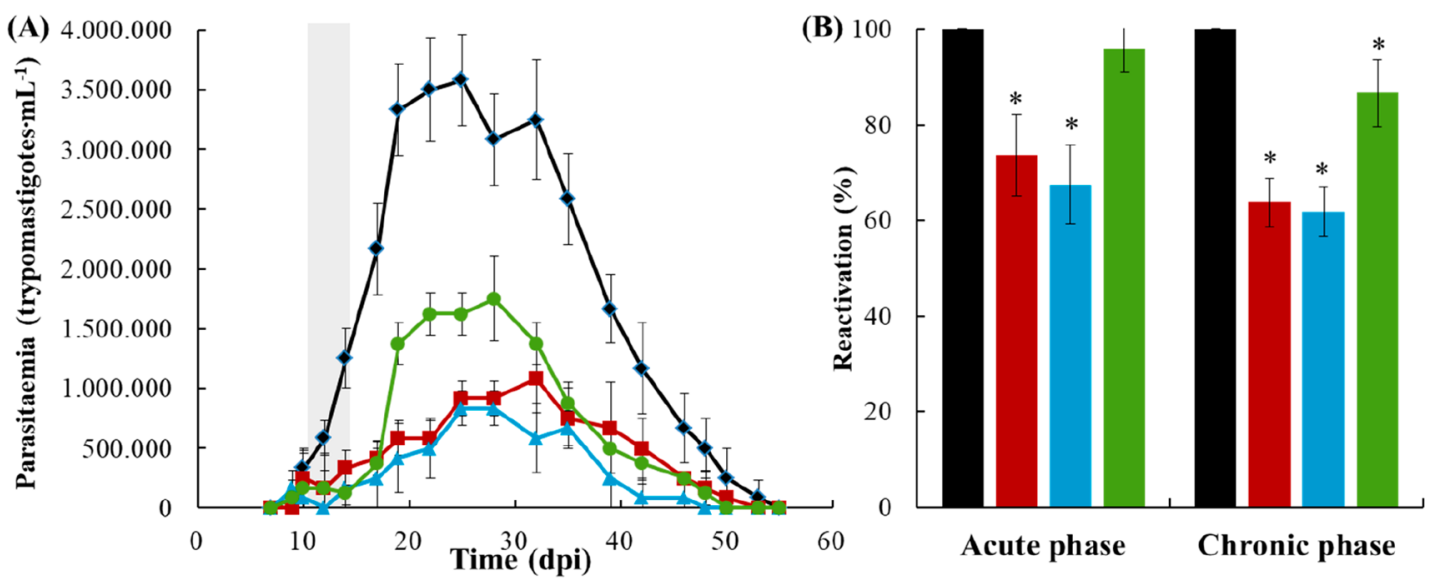

(C)

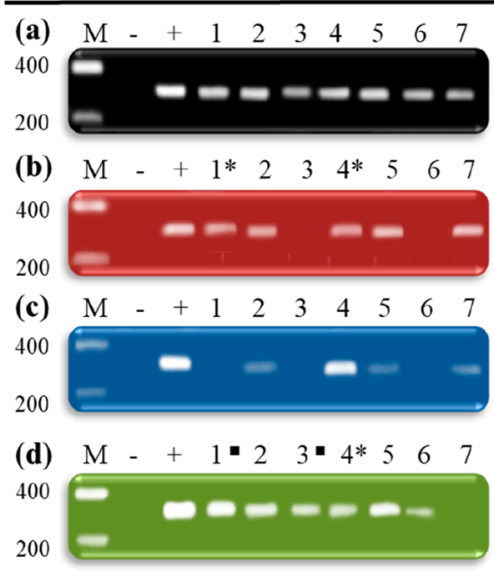

Chronic phase

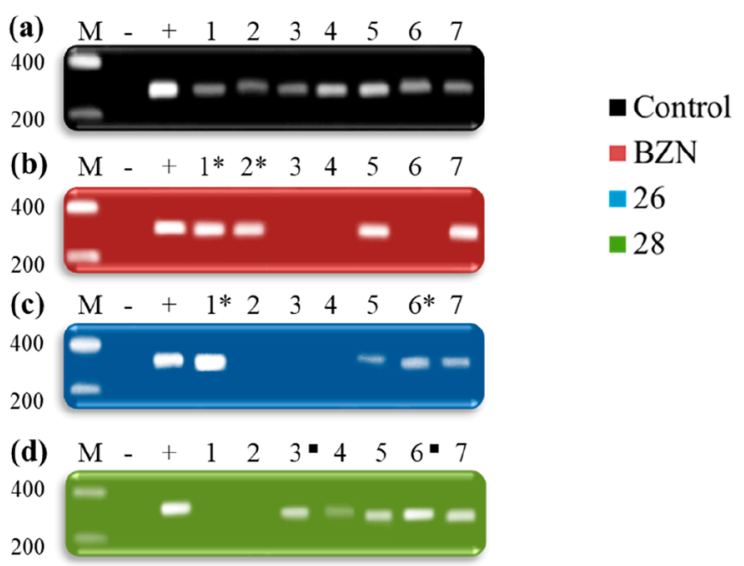

Figure 3. (A) Parasitaemia profiles of each group of mice infected with Trypanosoma cruzi and treated during the acute Chagas disease over a period of 60 days. Treatment days are represented in gray. Values are the means of three mice \pm standard deviation. Significant differences between untreated and treated mice for $\alpha=0.05$. (B) Parasitaemia reactivation by fresh blood in the chronic Chagas disease after the immunosuppression cycles for each group of mice treated during the acute and chronic phases of the disease. Values are the means of three mice \pm standard deviation. *, Significant differences between untreated and treated mice for $\alpha=0.05$. (C) PCR analysis of nine organs/tissues with the Trypanosoma cruzi spliced leader (SL) intergenic region sequence in the chronic Chagas disease for each group of mice treated during the acute and chronic phases of the disease. Lanes: (M) base pair marker, (-) PCR negative control, (+) PCR positive control, (1) adipose, (2) bone marrow, (3) brain, (4) esophagus, (5) heart, (6) lung, (7) muscle., $1 / 3$ of the corresponding organ/tissue PCR products showed banding on electrophoresis; $*, 2 / 3$ of the corresponding organ/tissue PCR products showed banding on electrophoresis.

reactivation (approximately 95 and $85 \%$ in acute and chronic phase, respectively). With this result, we hypothesized that compound 26 could be an effective antichagasic treatment. These results will be lately confirmed with the results obtained from tissue PCR.

In order to further evaluate the effectiveness of the compounds in acute and chronic $\mathrm{CD}$, the presence of nested $T$. cruzi parasites in target organs/tissues ${ }^{42}$ was measured by PCR after necropsy (145 dpi). Figure 3C resumes the PCR results for the different target organs/tissues in the 4 mice groups in both phases. As expected, untreated mice (Figure $3 \mathrm{C}(\mathrm{a}))$ showed the presence of parasites in every analyzed organs/tissues for both phases. In mice treated with BZN, brain and lung appeared free of parasites for the acute phase, and brain, esophagus and lung appeared free of parasites for the chronic phase (28.6 and $42.9 \%$ of parasite-free organs/ tissues, respectively). In accordance with previously obtained results, mice treated with compound 26 showed better results than those treated with BZN. In this case, adipose tissue, brain, and lung appeared free of parasites for the acute phase, and bone marrow, brain, esophagus for the chronic phase $(42.9 \%$ of parasite-free organs/tissues in both phases). In contrast, treatment with compound $\mathbf{2 8}$ did not decrease enough parasite levels in the analyzed tissues. As observed, compound 26 showed the best trypanocidal activity after the double checking of the cure, even better than that shown by BZN, confirming the partial curative effect in both phases of $C D$ at the tested dosage.

Otherwise, the immune response to $T$. cruzi infection was assessed by counting the immunoglobulin G (IgG) levels by indirect enzyme-linked immunosorbent assay (ELISA). ${ }^{44}$ The amount of IgG is directly associated with the parasitic load, and these experiments allowed the effectiveness of compounds evaluation in combination with the innate protection of the mice. ${ }^{42}$ The titer of anti-T. cruzi IgG in the different groups and the respective controls are shown in Figure S2. As observed, in the acute phase mice treated with compounds 26 or 28 showed lower IgG values than the treated with BZN at the beginning of the treatment becoming similar at the end, before and after IS. In the chronic phase, IgG values were similar between mice treated with compounds 26 and 28, treated with BZN and the control mice. These results confirm 
the antichagasic activity of both compounds 26 and 28, with compound 26 being more effective, especially in the acute phase. It has to be mentioned that the samples obtained after IS do not reflect data indicating infection rates, but rather confirm the IS suffered by the mice.

Moreover, splenomegaly is manifested in both acute and chronic phases on T. cruzi infected mice. This indicated the direct link between the enlargement of the spleen and the parasitic load. Figure S3 shows the weight percentage of the spleens for each group of mice. As observed, treated groups of mice demonstrated a smaller increase in the spleen weight when compared with the untreated (control) ones. Mice treated with compound 26 showed splenomegaly reduced by 49 and $38 \%$ in acute and chronic phases, respectively, and mice treated with compound $\mathbf{2 8}$ showed splenomegaly reduced by 37 and $48 \%$, in comparison with the untreated (control) mice. Both compounds showed spleen weight percentage similar to the BZN-treated mice, with mice treated with compound 26 being more active in the acute phase, as previous results demonstrated.

Finally, the metabolic abnormalities associated with the treatment were determined by measuring kidney, heart, and liver biochemical markers (Table S2), including values for uninfected mice. Although most of the clinical parameters showed alteration at 2 days post-treatment, they returned to normal levels in the measurements obtained on the necropsy day. Moreover, it is noteworthy that none of the mice died or lost more than $10 \%$ body mass during and/or after treatment. The low toxicity allows these compounds to be studied at higher doses, establishing an improved treatment schedule based on pharmacokinetic studies in order to reach a sterile cure.

Mode of Action (MoA) Studies. Metabolite Excretion. T. cruzi parasites are known to significantly reduce glucose metabolism catabolites to pyruvate, acetate, and succinate, instead of degrading glucose to $\mathrm{CO}_{2}$ and water, ${ }^{45}$ so epimastigotes of $T$. cruzi Arequipa strain (untreated and treated with 26 and 28 at $\mathrm{IC}_{25}$ concentrations) were analyzed by ${ }^{1} \mathrm{H}$ nuclear magnetic resonance $\left({ }^{1} \mathrm{H}\right.$ NMR) in order to measure different glucose metabolism catabolites. Figure 4 shows the percentage variation of excreted catabolites in treated parasites in comparison with control (untreated)

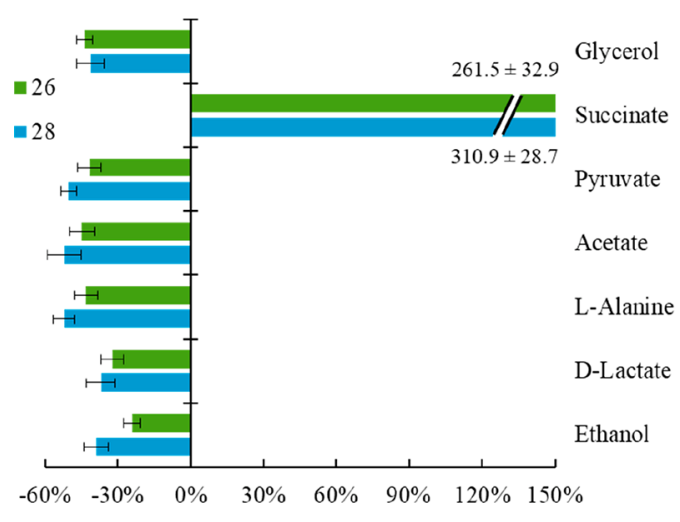

Figure 4. Variation among peaks of catabolites excreted by epimastigotes of Trypanosoma cruzi Arequipa strain exposed to $\mathbf{2 6}$ (green) and 28 (blue) at $\mathrm{IC}_{25}$ concentrations in comparison to control (untreated) parasites incubated $72 \mathrm{~h}$. Values constitute means of three separate determinations \pm standard deviation. Significant differences between untreated and treated parasites for $\alpha=0.05$. parasites. As shown, excretion of all analyzed catabolites was altered, with succinate being the most altered for both treatments with values $>250 \%$. According to the literature, an increase in excreted succinate may be closely related to a mitochondrial dysfunction. ${ }^{45,46}$ Therefore, mitochondrial stability assays were performed.

Mitochondrial Membrane Potential Measurement. Mitochondria play an essential role in the maintenance of the electrochemical gradient and disturbances in the membrane potential could lead to less DNA replication, RNA transcription, and therefore cell apoptosis and/or necrosis. In view of the possible mitochondrial dysfunction, acridine orange (AO) and rhodamine 123 (Rho) staining were performed to evaluate the integrity of this organelle by flow cytometry. Figure 5 shows the measured percentage variation after treatment at $\mathrm{IC}_{25}$ concentrations, as stated before. BZN reduces the mitochondrial membrane potential (35.4\%) due to its MoA. ${ }^{47}$ Parasites treated with compound 26 suffered a mitochondrial membrane depolarization of $40.6 \%$, while parasites treated with compound $\mathbf{2 8}$ reached a higher depolarization of $67 \%$. These results lead us to hypothesize that the antichagasic activity of the presented compounds may be related to an effect at the mitochondrial level: They could produce bioenergetic collapses, which precede $T$. cruzi death via necrosis in a mitochondrion-dependent manner, being the cause of the fast-acting trypanocidal activities of these compounds.

DNA and RNA Levels Measurement. As mentioned before, mitochondrial membrane potential alteration affects DNA replication and RNA transcription because of a decrease in ATP levels and a NADH/NAD ${ }^{+}$imbalance. ${ }^{45}$ Thus, DNA and RNA levels were quantified by flow cytometry, with their percentages summarized in Figure S4. Significant alteration was observed in every treatment, with BZN, 26, and 28 compared with the nontreated parasites. BZN inhibited nucleic acid levels up to $22 \%$. Meanwhile, treatments with compounds 26 and 28 produced an inhibition of nucleic acid levels of 47 and $62 \%$, respectively. These results bear out the possible MoA previously described. It must be noted that these inhibitions are due to not only an ATP deficit but also random nucleic acids degradation as a feature usually attributed to necrosis. ${ }^{48}$

T. cruzi Fe-SOD Enzyme Inhibition. Previous studies of our research group demonstrated the selective inhibition against Fe-SOD of selenium derivatives, ${ }^{13}$ one of the most relevant targets for $\mathrm{CD}$ treatment. Therefore, in view of the previous results and the well-known antioxidant system modulator activity of these compounds, ${ }^{33}$ compounds 26 and 28 ability to inhibit $\mathrm{Fe}-\mathrm{SOD}$ and/or $\mathrm{Cu} / \mathrm{SOD}$ enzyme was assessed. Figure 6 reveals the inhibition curve of both compounds against $\mathrm{Fe}$ SOD and human erythrocytes CuZn-SOD. Both compounds inhibit Fe-SOD enzyme activity, reaching $\mathrm{IC}_{50}$ values of 51.9 $\mu \mathrm{M}$ for compound 26 and $9.4 \mu \mathrm{M}$ for compound 28 . Moreover, compounds did not reach $50 \%$ inhibition of $\mathrm{Cu}$ / SOD even at $100 \mu \mathrm{M}$. These results indicated the high selectivity of compound $\mathbf{2 8}$ against the parasitic enzyme, allowing us to propose it as one of the possible targets or MoA. Even when its trypanocidal effect can be ultimately ascribed to the inhibition of this enzyme, the possibility of multitarget activity should however not be rejected.

\section{CONCLUSION}

In response to a dire need for new medications to treat $C D$, one chemical library of 41 leishmanicidal selenium amides and 
(a)

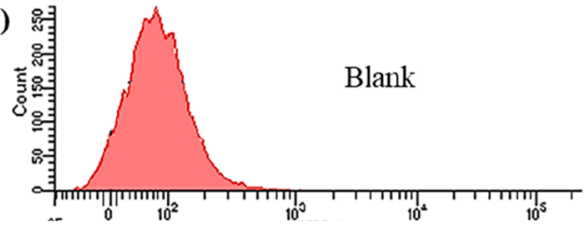

(c)

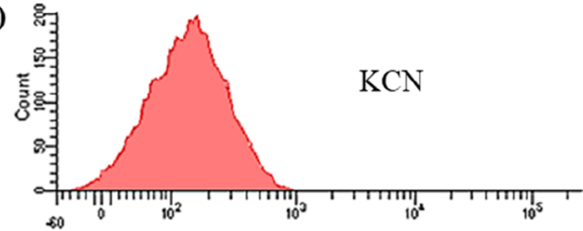

(b)

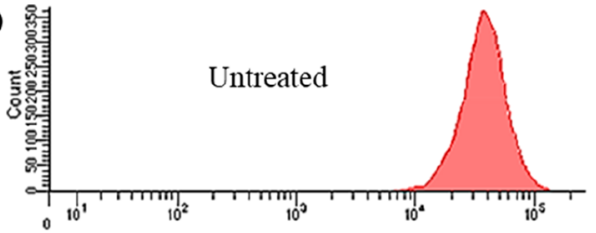

(d)

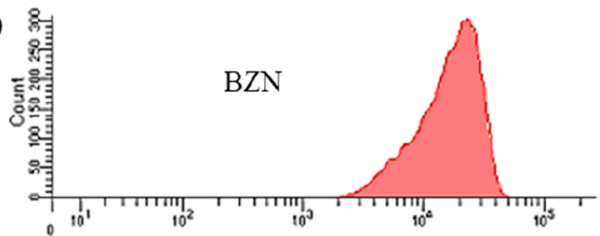

(e)

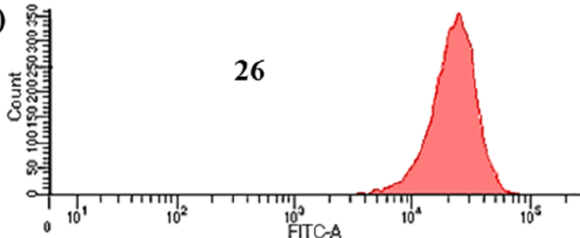

(f)

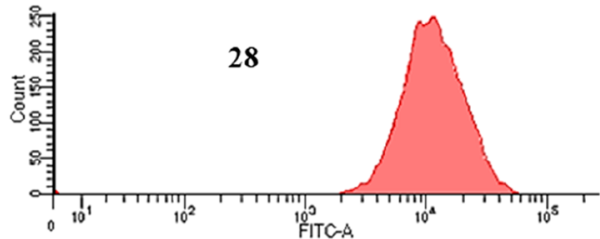

(g)

\begin{tabular}{cccc} 
& Inhibition (\%) & & Inhibition (\%) \\
\hline KCN & $95.5 \pm 6.1$ & BZN & $35.4 \pm 3.2$ \\
$\mathbf{2 6}$ & $40.6 \pm 4.7$ & $\mathbf{2 8}$ & $67.0 \pm 5.8$
\end{tabular}

Figure 5. Mitochondrial membrane potential from epimastigotes of Trypanosoma cruzi Arequipa strain exposed for $72 \mathrm{~h}$ to benznidazole (BZN) and compounds at their $\mathrm{IC}_{25}$ concentrations: (a) blank, (b) untreated (control), (c) potassium cyanide (KCN), (d) BZN, (e) 26, and (f) 28. (g) Inhibition, in percentage, on mitochondrial membrane potential with respect to untreated parasites. Values constitute means of three separate determinations \pm standard deviation. Significant differences between untreated and treated parasites for $\alpha=0.05$.

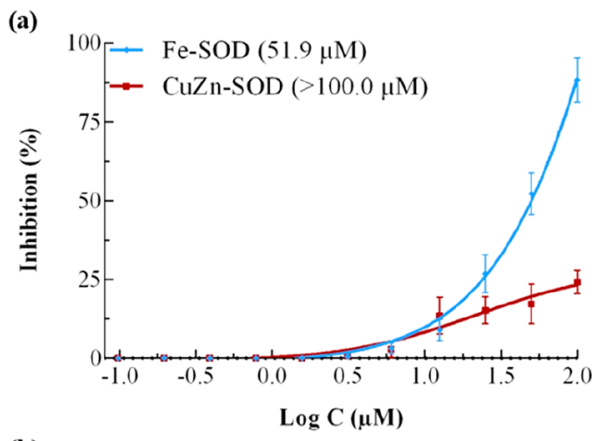

(b)

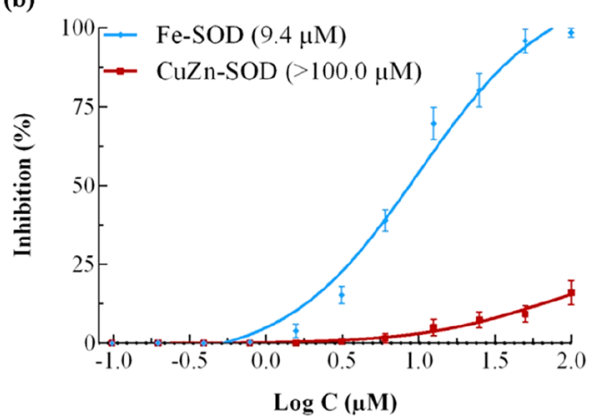

Figure 6. In vitro inhibition (\%) of Trypanosoma cruzi Fe-SOD (activity $42.0 \pm 3.8 \mathrm{U} \cdot \mathrm{mg}^{-1}$ ) and human erythrocytes CuZn-SOD (activity $47.3 \pm 4.1 \mathrm{U} \cdot \mathrm{mg}^{-1}$ ) for (a) 26 and (b) 28. Values constitute means of three separate determinations \pm standard deviation. Data in parentheses refer to the $\mathrm{IC}_{50}$ value.

phophoramidate derivatives were screened against T. cruzi. The most active and selective compounds against the epimastigote form (compounds 25, 26, 28, 29, and 33) were tested in the developed forms in vertebrate hosts (amastigotes and trypomastigotes). Taking into account the activity and selectivity of the derivatives, $\mathbf{2 6}$ and $\mathbf{2 8}$ were selected for the in vivo studies. Compound 26 exhibits a better profile than $\mathbf{2 8}$ and BZN, and it fulfils the most stringent in vitro requirements for potential antichagasic agents. It showed higher activity and lower toxicity than BZN after in vivo treatment, as indicated by different trials such as parasitemia monitoring, PCR, IS, or biochemical analysis. MoA analysis suggests a trypanocidal activity via necrosis in a mitochondrion-dependent manner through a bioenergetic collapse caused by a mitochondrial membrane depolarization. These findings suggest that these derivatives could be exploited and provide a step forward in the development of new antichagasic agents. It is worth considering higher doses and/or different treatment schedules, even combined therapies, to obtain a sterile cure.

\section{METHODS}

Chemistry. The compound library consists of 41 compounds containing bis(4-aminophenyl)diselenide ${ }^{33}$ or 4aminophenylselenocyanate ${ }^{33}$ entities as nucleus that have been decorated with aliphatic, cycloaliphatic, aromatic, and heteroaromatic substituents linked by an amide or phosphoramidate group. Structures are summarized in Figure 6. The synthesis and characterization of the molecules are reported in the literature. ${ }^{33}$ Briefly, amides derived from diselenide (compounds 4, 11 and 13) and selenocyanate (compounds 21-34) were synthesized by an amide bond coupling with the corresponding amino groups of these scaffolds and the corresponding carbonyl of the acid chlorides. ${ }^{33}$ Compounds $1-3,5-10,12$, and 14 were prepared or by the reduction with sodium borohydride of the corresponding selenocyanate analogues. $^{33}$ Finally, phosphoramidate derivatives were obtained by reaction between the phosphoryl chlorides and bis(4aminophenyl)diselenide (compounds 15-20) or 4aminophenylselenocyanate (compounds 35-41), respectively 
(unpublished). Briefly, derivatives 15-20 were obtained by reaction of a solution of bis(4-aminophenyl)diselenidein acetonitrile with the corresponding commercially available phosphoryl chlorides in a molar ratio $(1: 1)$ and triethylamine at $80{ }^{\circ} \mathrm{C}$ for $1 \mathrm{~h}$ under an inert atmosphere of nitrogen. Compounds 35-41 were obtained reacting 4-aminophenylselenocyanate, the corresponding phosphoryl chloride, in a molar ratio of $1: 2$, and trimethylamine in chloroform under nitrogen at $60{ }^{\circ} \mathrm{C}$ for $5 \mathrm{~h}$. Phosphoramidate derivatives (1520 and 35-41) were purified by flash chromatography using different gradients of hexane/ethyl acetate as eluents.

In Vitro Trypanocidal Activity. Screening against Extracellular Epimastigotes. T. cruzi epimastigotes of three different strains [Arequipa strain (MHOM/Pe/2011/Arequipa, DTU V), ${ }^{42}$ SN3 strain (IRHOD/CO/2008/SN3, DTU I) ${ }^{49}$ and Tulahuen strain (TINF/CH/1956/Tulahuen, DTU VI) $]^{42}$ were cultured at $28{ }^{\circ} \mathrm{C}$ in Gibco RPMI 1640 medium supplemented with $10 \%(v / v)$ heat-inactivated fetal bovine serum (FBS), $0.03 \mathrm{M}$ hemin, and $0.5 \%(w / v)$ BBL trypticase. ${ }^{50}$

Trypanocidal activity against epimastigotes was tested as previously described. ${ }^{42}$ In short, $5 \times 10^{5}$ epimastigotes $\cdot \mathrm{mL}^{-1}$ were treated by adding the tested selenocompounds and BZN to the corresponding well at a concentration range of 50-0.5 $\mu \mathrm{M}$ in 96 -well plates $\left(200 \mu \mathrm{L} \cdot \mathrm{well}^{-1}\right)$ for $48 \mathrm{~h}$. Untreated controls were also included. Subsequently, resazurin sodium salt (Sigma-Aldrich) was added, and the cells were incubated for further $24 \mathrm{~h}$. Finally, the absorbance was measured using a Sunrise absorbance reader, and the trypanocidal activity was expressed as the $\mathrm{IC}_{50}$ using GraphPad Prism 6 software. Each compound concentration was tested in triplicate in three independent experiments.

Cytotoxicity Test. Mammalian Vero cells (EACC No. 84113001 ), cultured as previously reported, ${ }^{41}$ were used to determine the cytotoxicity of the selenocompounds. ${ }^{42}$ In short, $1.25 \times 10^{4}$ Vero cells $\cdot \mathrm{mL}^{-1}$ were treated by adding the tested selenocompounds and BZN at a concentration range of 2000$50 \mu \mathrm{M}$ in 96 -well plates $\left(200 \mu \mathrm{L} \cdot \mathrm{well}^{-1}\right)$ at $37{ }^{\circ} \mathrm{C}$ for $48 \mathrm{~h}$. Untreated controls were also included. Subsequently, resazurin sodium salt (Sigma-Aldrich) was added, and the cells were incubated for a further $24 \mathrm{~h}$. Finally, cell viability was determined following the same procedure as described to assess the trypanocidal activity in the epimastigotes. Each compound concentration was tested in triplicate in three independent experiments.

Screening against Intracellular Amastigotes and Infected Cells. Trypanocidal activity against amastigotes was determined according to the literature reported previously. ${ }^{41}$ In short, $1 \times 10^{4}$ Vero cells $\cdot$ well $^{-1}$ were seeded in 24 -well plates and then infected with culture-derived trypomastigotes (obtained as previously described) ${ }^{42}$ at a multiplicity of infection (MOI) ratio of 1:10. After $24 \mathrm{~h}$ of infection, nonphagocyted trypomastigotes were washed, and the plates were treated by adding the tested selenocompounds and BZN to the corresponding well at a concentration range of 50-0.1 $\mu \mathrm{M}$ in $500 \mu \mathrm{L} \cdot \mathrm{well}^{-1}$. Untreated controls were also included. After $72 \mathrm{~h}$ of incubation, the trypanocidal effect was determined based on the counting of amastigotes and infected cells in methanol-fixed and Giemsa-stained preparations, and the activity was expressed as the $\mathrm{IC}_{50}$ using GraphPad Prism 6 software. Each compound concentration was tested in triplicate in three independent experiments.

Screening against Bloodstream Trypomastigotes. BTs (2 $\times 10^{6} \mathrm{BTs} \cdot \mathrm{mL}^{-1}$, obtained as previously described from infected $\mathrm{BALB} / \mathrm{c}$ mice $)^{51}$ were treated by adding the tested selenocompounds and $\mathrm{BZN}$ at a concentration range of 50$0.1 \mu \mathrm{M}$ in 96 -well plates $\left(200 \mu \mathrm{L} \cdot \mathrm{well}^{-1}\right)$ at $37{ }^{\circ} \mathrm{C}$. Untreated controls were also included. After $24 \mathrm{~h}$ of treatment, resazurin sodium salt (Sigma-Aldrich) was added, and the cells were incubated for a further $4 \mathrm{~h}$. Finally, trypanocidal activity was determined following the same procedure as described to assess the trypanocidal activity in the epimastigotes. Each compound concentration was tested in triplicate in three independent experiments.

In Vivo Trypanocidal Activity on BALB/c Mice. Ethics Statement. All animal work and maintenance was performed under RD53/2013 and approved by the Ethics Committee on Animal Experimentation (CEEA) of the University of Granada, Spain.

Infection and Treatment. Female BALB/c mice aged 1012 weeks and with a size of 20-24 g were divided into five groups ( $n=3$ per group): 0 , negative control group (uninfected and untreated mice); I, positive control group (infected and untreated mice); II, BZN group (infected mice treated with BZN); III, 26 group (infected mice treated with 26 ); and IV, 28 group (infected mice treated with 28).

Mice were infected by intraperitoneal injection of $5 \times 10^{5}$ BTs of T. cruzi Arequipa strain per mouse in $200 \mu \mathrm{L} \mathrm{PBS}{ }^{42}$ Subsequently, the treatment was intraperitoneally administered $(\sim 200 \mu \mathrm{L})$ once daily for 5 consecutive days.

The tested selenocompounds and BZN were prepared at 2 $\mathrm{mg} \cdot \mathrm{mL}^{-1}$ in an aqueous suspension vehicle containing $5 \%(\mathrm{v} /$ v) DMSO and $0.5 \%(w / v)$ hydroxypropyl methylcellulose, as previously reported. ${ }^{52}$ Compounds $\left(20 \mathrm{mg} \cdot \mathrm{kg}^{-1}\right.$ per day) were administered for 5 consecutive days (total dosages of $100 \mathrm{mg}$. $\mathrm{kg}^{-1}$ ), and vehicle only was administered in the negative and positive control groups. Treatments began when the infection was confirmed ( $9 \mathrm{dpi}$ ) for acute-phase-treated mice, and when it was established that the animals moved into the chronic phase (100 dpi, for chronic-phase-treated mice; Scheme 1).

Monitoring of Parasitaemia during the Acute Phase Treatment. Parasitemia levels were measured by counting BTs from peripheral blood drawn from the mandibular vein and diluted at a ratio of 1:100, as previously described. ${ }^{42}$ Fresh blood microscopic examination was performed until the day the parasitemia was undetected (Scheme 1). Parasitemia was expressed as parasites $\cdot \mathrm{mL}^{-1}$.

Immunosuppression. Immunosuppression was performed by intraperitoneal injection of three doses of $200 \mathrm{mg} \cdot \mathrm{kg}^{-1}$ of ISOPAC CP at 3-4 day intervals (Scheme 1), as previously reported. ${ }^{53}$ Mice were closely monitored for side effects or for secondary infections due to immunosuppression. Within 7 days after the last CP injection, parasitemia reactivation was determined by counting BTs according the procedure described for parasitemia in the acute phase. ${ }^{42}$

Mice Sacrifice, Blood Collection, and Organs/Tissues Extraction. On $145 \mathrm{dpi}$, the mice were euthanized using $\mathrm{CO}_{2}$, followed by exsanguination via cardiac puncture, and blood was collected. Nine target organs/tissues (adipose, bone marrow, brain, esophagus, heart, lung, muscle, spleen, and stomach) were then harvested ${ }^{42}$ and perfused with prewarmed PBS to avoid contamination with BTs. ${ }^{54}$ Finally, they were stored at $-80{ }^{\circ} \mathrm{C}$ until DNA extraction. In addition, spleens were weighed to assess splenomegaly. ${ }^{42}$

Tissue DNA Extraction, PCR, and Electrophoresis. DNA extraction of the post-mortem organs/tissues was performed using Wizard Genomic DNA Purification Kit, ${ }^{41}$ and the 
extracted DNA was subjected to amplification by PCR based on the spliced leader (SL) intergenic region sequence of $T$. cruzi (for detailed description, see literature reported previously). ${ }^{55}$ Finally, the PCR products were resolved by electrophoresis on a $2 \%$ agarose gel (containing GelRed nucleic gel stain) for $90 \mathrm{~min}$ at $90 \mathrm{~V}$.

ELISA Test. Serum samples were obtained from blood collected on several days post-infection (Scheme 1), processed according the method previously described, ${ }^{42}$ and aliquoted to the ELISA test and biochemical analysis, as mentioned below.

Circulating antibodies in serum against both antigens were quantitatively evaluated in triplicate by the ELISA test in 96well plates using diluted serum samples (1:80 in PBS), as previously described. ${ }^{41}$

Toxicity Test by Clinical Analysis. Serum samples obtained from blood in several days post-infection (Scheme 1) were sent to the Biochemical Service (University of Granada) to measure a series of biochemical parameters with the commercial Cromakit using a clinical chemistry analyzer (BS-200, Shenzhen Mindray Biomedical Electronics Co., LTD), as previously described. ${ }^{41}$

Mode of Action Studies. ${ }^{1} \mathrm{H}$ NMR Analysis of Excreted Metabolites. T. cruzi Arequipa $\left(5 \times 10^{5}\right.$ epimastigotes $\left.\cdot \mathrm{mL}^{-1}\right)$ were treated by adding the tested compounds at $\mathrm{IC}_{25}$ concentrations in $25 \mathrm{~cm}^{2}$ cell culture flasks at $28{ }^{\circ} \mathrm{C}$ for 72 h. Untreated controls were also included. Cultures were then centrifuged and filtered, and the metabolites of the supernatants were analyzed using a ${ }^{1} \mathrm{H}$ NMR spectrometer (Varian Direct Drive $500 \mathrm{MHz}$ Bruker) with AutoX probe, $\mathrm{D}_{2} \mathrm{O}$ as solvent, and 2,2-dimethyl-2-silapentane-5-sulfonate as the reference signal. ${ }^{56}$ Chemical shifts were expressed in parts per million (ppm), and analyses were conducted as previously reported. ${ }^{57}$

Flow Cytometry Analysis of Mitochondrial Membrane Potential and Nucleic Acid Levels. The untreated and treated epimastigotes of T. cruzi Arequipa described in the ${ }^{1} \mathrm{H}$ NMR analysis were collected by centrifugation, washed three times in PBS, and stained with $10 \mathrm{mg} \cdot \mathrm{mL}^{-1}$ Rho (Sigma-Aldrich) or AO (Sigma-Aldrich) dyes in $0.5 \mathrm{~mL}$ of PBS for $20 \mathrm{~min}^{58}$ Control epimastigotes with a fully depolarized mitochondrion were obtained by incubation for $40 \mathrm{~min}$ with $10 \mathrm{Mm} \mathrm{KCN}$ prior to Rho loading. ${ }^{59}$ Nonstained parasites were also included. After the elapsed time, epimastigotes were processed and analyzed by flow cytometry as previously reported. ${ }^{57}$

SOD Enzymatic Inhibition Analysis. The in vitro activities of either excreted Fe-SOD from T. cruzi (obtained as previously described $)^{57}$ and commercial copper/zinc superoxide dismutase $(\mathrm{Cu} / \mathrm{Zn}-\mathrm{SOD})$ from human erythrocytes (Sigma-Aldrich) were evaluated using the method previously described $^{60}$ after incubation with a concentration range of compound from 100 to $0.1 \mu \mathrm{M}$.

Statistical Analyses. Statistical analyses were performed with the SPSS v21.0 software (IBM Corp; Armonk, NY). The $t$-test for paired samples was used to verify whether there were differences between the assays used. Differences were considered significant when the $p$-value was less than 0.05 . Also statistical studies based on contingency tables (prevalence) were conducted.

\section{ASSOCIATED CONTENT}

\section{SI Supporting Information}

The Supporting Information is available free of charge at https://pubs.acs.org/doi/10.1021/acsinfecdis.1c00048.
Number of amastigotes of T. cruzi Arequipa strain per Vero cell. Anti-T. cruzi immunoglobulin G levels at different days postinfection. Weight percentage of spleens in the chronic Chagas disease. Nucleic acids levels of $T$. cruzi Arequipa strain. Activity of benznidazole and selenocompounds tested against cultured epimastigote form of $T$. cruzi strains, and toxicity against cultured Vero cells. Clinical analysis. (PDF)

\section{AUTHOR INFORMATION}

\section{Corresponding Author}

Clotilde Marín - Department of Parasitology, Instituto de Investigación Biosanitaria (ibs. Granada), Hospitales Universitarios De Granada/University of Granada, 18071 Granada, Spain; 이이.org/0000-0002-4316-2742; Email: cmaris@ugr.es

\section{Authors}

Rubén Martín-Escolano - Laboratory of Molecular \& Evolutionary Parasitology, RAPID group, School of Biosciences, University of Kent, Canterbury CT2 7NJ, United Kingdom; (1) orcid.org/0000-0002-6262-9344

Mikel Etxebeste-Mitxeltorena - Facultad de Farmacia y Nutrición, Departamento de Tecnología y Química Farmacéuticas, Universidad de Navarra, E-31008 Pamplona, Spain; Instituto de Salud Tropical, Universidad de Navarra (ISTUN), E-31008 Pamplona, Spain; Instituto de Investigaciones Sanitarias de Navarra (IdiSNA), E-31008 Pamplona, Spain

Javier Martín-Escolano - Servicio de Microbiologia Clinica y Enfermedades Infecciosas, Hospital General Universitario Gregorio Marañón, 28007 Madrid, Spain; Instituto de Investigación, Sanitaria Gregorio Marañón (IiSGM), 28009 Madrid, Spain

Daniel Plano - Facultad de Farmacia y Nutrición, Departamento de Tecnología y Química Farmacéuticas, Universidad de Navarra, E-31008 Pamplona, Spain; Instituto de Salud Tropical, Universidad de Navarra (ISTUN), E-31008 Pamplona, Spain; Instituto de Investigaciones Sanitarias de Navarra (IdiSNA), E-31008 Pamplona, Spain

María J. Rosales - Department of Parasitology, Instituto de Investigación Biosanitaria (ibs. Granada), Hospitales Universitarios De Granada/University of Granada, 18071 Granada, Spain

Socorro Espuelas - Facultad de Farmacia y Nutrición, Departamento de Tecnología y Química Farmacéuticas, Universidad de Navarra, E-31008 Pamplona, Spain; Instituto de Salud Tropical, Universidad de Navarra (ISTUN), E-31008 Pamplona, Spain; Instituto de Investigaciones Sanitarias de Navarra (IdiSNA), E-31008 Pamplona, Spain

Esther Moreno - Facultad de Farmacia y Nutrición, Departamento de Tecnología y Química Farmacéuticas, Universidad de Navarra, E-31008 Pamplona, Spain; Instituto de Salud Tropical, Universidad de Navarra (ISTUN), E-31008 Pamplona, Spain; Instituto de Investigaciones Sanitarias de Navarra (IdiSNA), E-31008 Pamplona, Spain

Manuel Sánchez-Moreno - Department of Parasitology, Instituto de Investigación Biosanitaria (ibs. Granada), 
Hospitales Universitarios De Granada/University of Granada, 18071 Granada, Spain

Carmen Sanmartín - Facultad de Farmacia y Nutrición, Departamento de Tecnología y Química Farmacéuticas, Universidad de Navarra, E-31008 Pamplona, Spain; Instituto de Salud Tropical, Universidad de Navarra (ISTUN), E-31008 Pamplona, Spain; Instituto de Investigaciones Sanitarias de Navarra (IdiSNA), E-31008 Pamplona, Spain; 이이이.org/0000-0003-3431-7826

Complete contact information is available at: https://pubs.acs.org/10.1021/acsinfecdis.1c00048

\section{Notes}

The authors declare no competing financial interest.

\section{ACKNOWLEDGMENTS}

This work was financially supported by the Ministerio de Economia, Industria y Competitividad (CONSOLIDER CSD2010-00065 and CTQ2017-90852-REDC). R.M.-E. is grateful for the fellowship from the Alfonso Martín Escudero Foundation.

\section{ABBREVIATIONS}

$\mathrm{AO}$, acridine orange; BTs, bloodstream trypomastigotes; BZN, benznidazole; CD, Chagas disease; $\mathrm{CP}$, cyclophosphamide monohydrate; DNDi, Drug for Neglected Diseases initiative; DTU, discrete typing unit; ELISA, enzyme-linked immunosorbent assay; FBS, fetal bovine serum; $\mathrm{IC}_{50}$, inhibitory concentration 50; Ig, immunoglobulin; MoA, mode of action; MOI, multiplicity of infection; NFX, nifurtimox; Rho, rhodamine 123; Se, selenium; SI, selectivity index; SL, splice leader; SOD, superoxide dismutase; ${ }^{1} \mathrm{H}$ NMR, ${ }^{1} \mathrm{H}$ nuclear magnetic resonance

\section{REFERENCES}

(1) Bern, C. (2015) Chagas' Disease. N. Engl. J. Med. 373 (5), 456466.

(2) Drugs for Neglected Diseases Initiative. (December 2020) Symptoms, transmission, and current treatments for Chagas disease, https://www.dndi.org/diseases-projects/chagas/chagas-diseasebackground/ (accessed January 10, 2021).

(3) Hernández, C., Vera, M. J., Cucunubá, Z., Flórez, C., Cantillo, O., Buitrago, L. S., González, M. S., Ardila, S., Dueñas, L. Z., Tovar, R., Forero, L. F., and Ramírez, J. D. (2016) High-resolution molecular typing of Trypanosoma cruzi in 2 large outbreaks of acute Chagas disease in Colombia. J. Infect. Dis. 214 (8), 1252-1255.

(4) Pérez-Molina, J. A., Norman, F., and López-Vélez, R. (2012) Chagas disease in non-endemic countries: epidemiology, clinical presentation and treatment. Curr. Infect. Dis. Rep. 14 (3), 263-274.

(5) Requena-Méndez, A., Aldasoro, E., de Lazzari, E., Sicuri, E., Brown, M., Moore, D. A., Gascon, J., and Muñoz, J. (2015) Prevalence of Chagas disease in Latin-American migrants living in Europe: a systematic review and meta-analysis. PLoS Neglected Trop. Dis. 9 (2), No. e0003540.

(6) Kessler, R. L., Contreras, V. T., Marliére, N. P., Aparecida Guarneri, A., Villamizar Silva, L. H., Mazzarotto, G. A. C. A., Batista, M., Soccol, V. T., Krieger, M. A., and Probst, C. M. (2017) Recently differentiated epimastigotes from Trypanosoma cruzi are infective to the mammalian host. Mol. Microbiol. 104 (5), 712-736.

(7) Cardillo, F., de Pinho, R. T., Antas, P. R. Z., and Mengel, J. (2015) Immunity and immune modulation in Trypanosoma cruzi infection. Pathog. Dis. 73 (9), No. ftv082.

(8) Cunha-Neto, E., and Chevillard, C. (2014) Chagas disease cardiomyopathy: immunopathology and genetics. Mediators Inflammation 2014, 683230.
(9) Gaspar, L., Moraes, C. B., Freitas-Junior, L., Ferrari, S., Costantino, L., Costi, M., Coron, R., Smith, T., Siqueira-Neto, J., McKerrow, J., and Cordeiro-Da-Silva, A. (2015) Current and future chemotherapy for Chagas disease. Curr. Med. Chem. 22 (37), 42934312.

(10) Martín-Escolano, J., Medina-Carmona, E., and MartínEscolano, R. (2020) Chagas disease: current view of an ancient and global chemotherapy challenge. ACS Infect. Dis. 6, 2830-2843.

(11) Wilkinson, S. R., Taylor, M. C., Horn, D., Kelly, J. M., and Cheeseman, I. (2008) A mechanism for cross-resistance to nifurtimox and benznidazole in trypanosomes. Proc. Natl. Acad. Sci. U. S. A. 105 (13), 5022-5027.

(12) Villarreal, D., Barnabé, C., Sereno, D., and Tibayrenc, M. (2004) Lack of correlation between in vitro susceptibility to benznidazole and phylogenetic diversity of Trypanosoma cruzi, the agent of Chagas disease. Exp. Parasitol. 108 (1-2), 24-31.

(13) Martín-Montes, Á., Plano, D., Martín-Escolano, R., Alcolea, V., Díaz, M., Pérez-Silanes, S., Espuelas, S., Moreno, E., Marín, C., Gutiérrez-Sánchez, R., et al. (2017) Library of seleno-compounds as novel agents against Leishmania species. Antimicrob. Agents Chemother. 61 (6), No. e02546-16.

(14) Díaz, M., de Lucio, H., Moreno, E., Espuelas, S., Aydillo, C., Jiménez-Ruiz, A., Toro, M. A., Gutierrez, K. J., Martinez-Merino, V., Cornejo, A., et al. (2019) Synthesis and leishmanicidal activity of novel urea, thiourea, and selenourea derivatives of diselenides. Antimicrob. Agents Chemother. 63 (5), No. e02200-18.

(15) Al-Tamimi, A. M. S., Etxebeste-Mitxeltorena, M., Sanmartín, C., Jiménez-Ruiz, A., Syrjänen, L., Parkkila, S., Selleri, S., Carta, F., Angeli, A., and Supuran, C. T. (2019) Discovery of new organoselenium compounds as antileishmanial agents. Bioorg. Chem. 86, 339-345.

(16) Garnica, P., Etxebeste-Mitxeltorena, M., Plano, D., Moreno, E., Espuelas, S., Antonio Palop, J., Jiménez-Ruiz, A., and Sanmartín, C. (2020) Pre-clinical evidences of the antileishmanial effects of diselenides and selenocyanates. Bioorg. Med. Chem. Lett. 30 (17), 127371.

(17) Angeli, A., Etxebeste-Mitxeltorena, M., Sanmartín, C., Espuelas, S., Moreno, E., Azqueta, A., Parkkila, S., Carta, F., and Supuran, C. T. (2020) Tellurides bearing sulfonamides as novel inhibitors of leishmanial carbonic anhydrase with potent antileishmanial activity. J. Med. Chem. 63 (8), 4306-4314.

(18) Suradji, E. W., Hatabu, T., Kobayashi, K., Yamazaki, C., Abdulah, R., Nakazawa, M., Nakajima-Shimada, J., and Koyama, H. (2011) Selenium-induced apoptosis-like cell death in Plasmodium falciparum. Parasitology 138 (14), 1852-1862.

(19) Eze, J. I., Okeke, M. C., Ngene, A. A., Omeje, J. N., and Abonyi, F. O. (2013) Effects of dietary selenium supplementation on parasitemia, anemia and serum proteins of Trypanosoma brucei brucei infected rats. Exp. Parasitol. 135 (2), 331-336.

(20) Dkhil, M. A., Khalil, M. F., Diab, M. S. M., Bauomy, A. A., Santourlidis, S., Al-Shaebi, E. M., and Al-Quraishy, S. (2019) Evaluation of nanoselenium and nanogold activities against murine intestinal schistosomiasis. Saudi J. Biol. Sci. 26 (7), 1468-1472.

(21) Rivera, M. T., De Souza, A. P., Moreno, A. H. M., Xavier, S. S., Gomes, J. A. S., Rocha, M. O. C., Correa-Oliveira, R., Nève, J., Vanderpas, J., and Araújo-Jorge, T. C. (2002) Progressive Chagas' cardiomyopathy is associated with low selenium levels. Am. J. Trop. Med. Hyg. 66 (6), 706-712.

(22) Pereira de Souza, A., Sieberg, R., Li, H., Cahill, H. R., Zhao, D., Araújo-Jorge, T., Tanowitz, H. B., and Jelicks, L. A. (2010) The role of selenium in intestinal motility and morphology in a murine model of Typanosoma cruzi infection. Parasitol. Res. 106 (6), 1293-1298.

(23) Alvarenga Americano do Brasil, P. E., Pereira de Souza, A., Hasslocher-Moreno, A. M., Xavier, S. S., Lambert Passos, S. R., de Fátima Ramos Moreira, M., Santini de Oliveira, M., Sperandio da Silva, G. M., Magalhães Saraiva, R., Santos de Aguiar Cardoso, C., et al. (2014) Selenium treatment and chagasic cardiopathy (STCC): study protocol for a double-blind randomized controlled trial. Trials 15 (1), 338. 
(24) de Souza, A. P., Jelicks, L. A., Tanowitz, H. B., Olivieri, B. P., Medeiros, M. M., Oliveira, G. M., Pires, A. R. C., dos Santos, A. M., and Araújo-Jorge, T. C. (2010) The benefits of using selenium in the treatment of Chagas disease: prevention of right ventricle chamber dilatation and reversion of Trypanosoma cruzi-induced acute and chronic cardiomyopathy in mice. Mem. Inst. Oswaldo Cruz 105 (6), $746-751$.

(25) Pizzo, C., Faral-Tello, P., Salinas, G., Fló, M., Robello, C., Wipf, P., and Graciela Mahler, S. (2012) Selenosemicarbazones as potent Cruzipain inhibitors and their antiparasitic properties against Trypanosoma cruzi. MedChemComm 3 (3), 362-368.

(26) Jardim, G. A. M., Reis, W. J., Ribeiro, M. F., Ottoni, F. M., Alves, R. J., Silva, T. L., Goulart, M. O. F., Braga, A. L., MennaBarreto, R. F. S., Salomão, K., et al. (2015) On the investigation of hybrid quinones: synthesis, electrochemical studies and evaluation of trypanocidal activity. RSC Adv. 5 (95), 78047-78060.

(27) Jardim, G. A. M., Silva, T. L., Goulart, M. O. F., de Simone, C. A., Barbosa, J. M. C., Salomão, K., de Castro, S. L., Bower, J. F., and da Silva Júnior, E. N. (2017) Rhodium-catalyzed C-H bond activation for the synthesis of quinonoid compounds: significant anti-Trypanosoma cruzi activities and electrochemical studies of functionalized quinones. Eur. J. Med. Chem. 136, 406-419.

(28) Kharma, A., Jacob, C., Bozzi, Í. A. O., Jardim, G. A. M., Braga, A. L., Salomão, K., Gatto, C. C., Silva, M. F. S., Pessoa, C., Stangier, M., et al. (2020) Electrochemical selenation/cyclization of quinones: a rapid, green and efficient access to functionalized trypanocidal and antitumor compounds. Eur. J. Org. Chem. 2020 (29), 4474-4486.

(29) Chao, M. N., Storey, M., Li, C., Rodríguez, M. G., Di Salvo, F., Szajnman, S. H., Moreno, S. N. J., Docampo, R., and Rodriguez, J. B. (2017) Selenium-containing analogues of WC-9 are extremely potent inhibitors of Trypanosoma cruzi proliferation. Bioorg. Med. Chem. 25 (24), 6435-6449.

(30) Alcolea, V., and Pérez-Silanes, S. (2020) Selenium as an interesting option for the treatment of Chagas disease: a review. Eur. J. Med. Chem. 206 (2020), 112673.

(31) Drugs for Neglected Diseases Initiative. (June 8, 2020) Target product profile for Chagas disease, https://www.dndi.org/diseasesprojects/chagas/chagas-target-product-profile/ (accessed Jan 10, 2021).

(32) Zingales, B. (2018) Trypanosoma cruzi genetic diversity: something new for something known about Chagas disease manifestations, serodiagnosis and drug sensitivity. Acta Trop. 184, $38-52$.

(33) Etxebeste-Mitxeltorena, M., Plano, D., Espuelas, S., Moreno, E., Aydillo, C., Jiménez-Ruiz, A., Soriano, J. C. G., and Sanmartín, C. (2020) New amides containing selenium as potent leishmanicidal agents targeting trypanothione reductase. Antimicrob. Agents Chemother. 65 (1), No. e00524-20.

(34) Katsuno, K., Burrows, J. N., Duncan, K., Van Huijsduijnen, R. H., Kaneko, T., Kita, K., Mowbray, C. E., Schmatz, D., Warner, P., and Slingsby, B. T. (2015) Hit and lead criteria in drug discovery for infectious diseases of the developing world. Nat. Rev. Drug Discovery 14 (11), 751-758.

(35) Romanha, A. J., Castro, S. L., Soeiro, C., Lannes-Vieira, J., Ribeiro, I., Talvani, A., Bourdin, B., Blum, B., Olivieri, B., Zani, C., et al. (2010) In vitro and in vivo experimental models for drug screening and development for Chagas disease. Mem. Inst. Oswaldo Cruz 105, 233-238.

(36) Chatelain, E. (2015) Chagas disease drug discovery: toward a new era. J. Biomol. Screening 20 (1), 22-35.

(37) de Rycker, M., O’Neill, S., Joshi, D., Campbell, L., Gray, D. W., and Fairlamb, A. H. (2012) A static-cidal assay for Trypanosoma brucei to aid hit prioritisation for progression into drug discovery programmes. PLoS Neglected Trop. Dis. 6 (11), No. e1932.

(38) Sánchez-Valdéz, F. J., Padilla, A., Wang, W., Orr, D., and Tarleton, R. L. (2018) Spontaneous dormancy protects Trypanosoma cruzi during extended drug exposure. eLife 7, No. e34039.
(39) Scarim, C. B., Jornada, D. H., Chelucci, R. C., de Almeida, L., dos Santos, J. L., and Chung, M. C. (2018) Current advances in drug discovery for Chagas disease. Eur. J. Med. Chem. 155, 824-838.

(40) Chatelain, E., and Konar, N. (2015) Translational challenges of animal models in Chagas disease drug development: a review. Drug Des., Dev. Ther. 9, 4807-4823.

(41) Martín-Escolano, R., Molina-Carreño, D., Delgado-Pinar, E., Martin-Montes, Á., Clares, M. P., Medina-Carmona, E., PitarchJarque, J., Martín-Escolano, J., Rosales, M. J., García-España, E., Sánchez-Moreno, M., and Marín, C. (2019) New polyamine drugs as more effective antichagas agents than benznidazole in both the acute and chronic phases. Eur. J. Med. Chem. 164, 27-46.

(42) Martín-Escolano, R., Moreno-Viguri, E., Santivanez-Veliz, M., Martin-Montes, A., Medina-Carmona, E., Paucar, R., Marín, C., Azqueta, A., Cirauqui, N., Pey, A. L., Pérez-Silanes, S., and SánchezMoreno, M. (2018) Second generation of Mannich base-type derivatives with in vivo activity against Trypanosoma cruzi. J. Med. Chem. 61 (13), 5643-5663.

(43) Bustamante, J. M., Craft, J. M., Crowe, B. D., Ketchie, S. A., and Tarleton, R. L. (2014) New, combined, and reduced dosing treatment protocols cure Trypanosoma cruzi infection in mice. J. Infect. Dis. 209 (1), 150-162.

(44) López-Céspedes, Á., Villagrán, E., Briceño Álvarez, K., De Diego, J. A., Hernández-Montiel, H. L., Saldaña, C., Sãnchez-Moreno, M., and Marín, C. (2012) Trypanosoma cruzi: seroprevalence detection in suburban population of Santiago de Querétaro (Mexico). Sci. World J. 2012, 914129.

(45) Bringaud, F., Rivière, L., and Coustou, V. (2006) Energy metabolism of trypanosomatids: adaptation to available carbon sources. Mol. Biochem. Parasitol. 149 (1), 1-9.

(46) Wen, J.-J., Gupta, S., Guan, Z., Dhiman, M., Condon, D., Lui, C., and Garg, N. J. (2010) Phenyl- $\alpha$-tert-butyl-nitrone and benzonidazole treatment controlled the mitochondrial oxidative stress and evolution of cardiomyopathy in chronic chagasic rats. J. Am. Coll. Cardiol. 55 (22), 2499-2508.

(47) Hall, B. S., and Wilkinson, S. R. (2012) Activation of benznidazole by trypanosomal type I nitroreductases results in glyoxal formation. Antimicrob. Agents Chemother. 56 (1), 115-123.

(48) Verma, N. K., Singh, G., and Dey, C. S. (2007) Miltefosine induces apoptosis in arsenite-Resistant Leishmania donovani promastigotes through mitochondrial dysfunction. Exp. Parasitol. 116 (1), 113.

(49) Téllez-Meneses, J., Mejía-Jaramillo, A. M., and Triana-Chávez, O. (2008) Biological characterization of Trypanosoma cruzi stocks from domestic and sylvatic vectors in Sierra Nevada of Santa Marta, Colombia. Acta Trop. 108, 26-34.

(50) Kendall, G., Wilderspin, A. F., Ashall, F., Miles, M. A., and Kelly, J. M. (1990) Trypanosoma cruzi glycosomal glyceraldehyde-3phosphate dehydrogenase does not conform to the 'Hotspot' topogenic signal model. EMBO J. 9 (9), 2751-2758.

(51) Pless-Petig, G., Metzenmacher, M., Türk, T. R., and Rauen, U. (2012) Aggravation of cold-induced injury in Vero-B4 cells by RPMI 1640 medium - identification of the responsible medium components. BMC Biotechnol. 12, 73.

(52) Francisco, A. F., Jayawardhana, S., Lewis, M. D., White, K. L., Shackleford, D. M., Chen, G., Saunders, J., Osuna-Cabello, M., Read, K. D., Charman, S. A., et al. (2016) Nitroheterocyclic drugs cure experimental Trypanosoma cruzi infections more effectively in the chronic stage than in the acute stage. Sci. Rep. 6, 35351.

(53) Francisco, A. F., Lewis, M. D., Jayawardhana, S., Taylor, M. C., Chatelain, E., and Kelly, J. M. (2015) Limited ability of posaconazole to cure both acute and chronic Trypanosoma cruzi infections revealed by highly sensitive in vivo imaging. Antimicrob. Agents Chemother. 59 (8), 4653-4661.

(54) Ye, X., Ding, J., Zhou, X., Chen, G., and Liu, S. F. (2008) Divergent roles of endothelial NF-KB in multiple organ injury and bacterial clearance in mouse models of sepsis. J. Exp. Med. 205 (6), 1303-1315. 
(55) Paucar, R., Martín-Escolano, R., Moreno-Viguri, E., Azqueta, A., Cirauqui, N., Marín, C., Sánchez-Moreno, M., and Pérez-Silanes, S. (2019) Rational modification of Mannich base-type derivatives as novel antichagasic compounds: synthesis, in vitro and in vivo evaluation. Bioorg. Med. Chem. 27 (17), 3902-3917.

(56) Fernandez-Becerra, C., Sanchez-Moreno, M., Osuna, A., and Opperdoes, F. R. (1997) Comparative aspects of energy metabolism in plant trypanosomatids. J. Eukaryotic Microbiol. 44 (5), 523-529.

(57) Martín-Escolano, R., Aguilera-Venegas, B., Marín, C., MartínMontes, Á., Martín-Escolano, J., Medina-Carmona, E., Arán, V. J., and Sánchez-Moreno, M. (2018) Synthesis and biological in vitro and in vivo evaluation of 2-(5-nitroindazol-1-Yl)ethylamines and related compounds as potential therapeutic alternatives for Chagas disease. ChemMedChem 13 (19), 2104-2118.

(58) Sandes, J. M., Fontes, A., Regis-da-Silva, C. G., de Castro, M. C. A., Lima-Junior, C. G., Silva, F. P. L., Vasconcellos, M. L. A. A., and Figueiredo, R. C. B. Q. (2014) Trypanosoma cruzi cell death induced by the Morita-Baylis-Hillman adduct 3-hydroxy-2-methylene-3-(4nitrophenylpropanenitrile). PLoS One 9 (4), No. e93936.

(59) Abengózar, M. Á., Cebrián, R., Saugar, J. M., Gárate, T., Valdivia, E., Martínez-Bueno, M., Maqueda, M., and Rivas, L. (2017) Enterocin AS-48 as evidence for the use of bacteriocins as new leishmanicidal agents. Antimicrob. Agents Chemother. 61 (4), No. e02288-16.

(60) Beyer, W. F., and Fridovich, I. (1987) Assaying for superoxide dismutase activity: some large consequences of minor changes in conditions. Anal. Biochem. 161 (2), 559-566. 